\title{
Estimation of Carbon Stock Monetary Value of a Tropical Rainforest in Nigeria
}

\author{
Oluwayinka S. Oke \\ Department of Forestry and Wood Technology, Federal University of Technology Akure, \\ P.M.B. 704, Akure, Nigeria
}

\begin{abstract}
The study estimated the carbon stock contents of a lowland rainforest in Nigeria, Okomu National Park. Four major Carbon pools were estimated, they were: above-ground biomass; below-ground biomass: dead wood; and litter. Nested plot design was used for sample plot demarcation. All trees (living and dead) with Dbh $\geq 10 \mathrm{~cm}$ were enumerated within the $50 \mathrm{~m} \mathrm{X} 50 \mathrm{~m}$ and $20 \mathrm{~m} \mathrm{X} 20 \mathrm{~m}$ plots, while the $1 \mathrm{~m} \mathrm{X} 1 \mathrm{~m}$ quadrant was for litter samples collection. Core samples and sub-samples were collected from live tree and dead wood respectively. The total carbon stock estimated for the study area was 177.58 tons/ha, of which above-ground biomass accounted for 134.01 tons/ha and below-ground biomass was 33.50 tons/ha. Dead wood was 6.05 tons/ha while litter was 4.02 tons/ha. The Carbondioxide equivalent was estimated to be 651.14 tons/ha. The monetary value for the carbon stock estimated at $\$ 4 / \mathrm{tCO} 2$ was $\$ 52,674,679$. Thus, carbon sequestration is one of the significant ecosystem services provided by mature rainforests.
\end{abstract}

Keywords: Carbon pool, Rainforest, Ecosystem Service, Climate Change, Forest Management

DOI: $10.7176 / \mathrm{JRDM} / 63-06$

Publication date:March $31^{\text {st }} 2020$

\section{INTRODUCTION}

Okomu National Park is one of the Parks containing the remaining lowland rainforest ecosystem in Nigeria (Ejidike and Okosodo 2007). It is a mature forest housing a lot of biodiversity. The focus of management as with most National Parks has traditionally been focused on the conservation of wildlife species and most research studies on the Park has been focused on the same. This is evident in the studies conducted by Akinsorotan et al. (2011), Aremu et al. (2012), Obasogie and Ogunjemite (2014), Ojianwuna (2015), and Amusa (2016). The Park provided refuge for many threatened species, including the white-throated monkey (Cercopithecus erythrogaster) which is a major source of animal protein to people living in the surrounding communities and also sold commercially for financial benefits (Oates 1995, Ajayi 2011). In a study conducted by Morgan et al. (2011), the Park was classified as one of the exceptional priority conservation sites in Nigeria. However, Ogunjemite et al. (2007) and Aremu et al. (2012) stated that the Park is facing a major problem due to anthropogenic factors including illegal logging activities, poaching and habitat encroachment, overgrazing and deforestation. Out of the $202.24 \mathrm{~km}^{2}$ of land constituted for the Park, only $181 \mathrm{~km}^{2}$ is currently being managed actively by the Park management, this is because there is dispute on the remaining $21.24 \mathrm{~km}^{2}$ of land.

This is not necessarily because the local people are not aware of the importance of the protected area. A study carried out by Ogunjimi et al. (2012) revealed that although the local people are aware of the importance and limits of the ecosystem of the Park, their low level of education as well as the need to satisfy their considerably large family are the reasons for their continued degradation and unsustainable exploitation of these resources. Local communities, according to Tessema et al. (2007), though viewed protected areas and wildlife resources as essential resources, are unwilling to aid conservation works due to perceive lack of benefit. Studies that contribute to the management of the Park as well as improving the livelihood of local communities in light of future climate change scenarios are lacking and are therefore needed as stated by Assaye (2014). The forest ecosystem which provides shelter for the wildlife species being protected in the Park also sequester a lot of carbon through photosynthesis and this can be traded as obtainable under REDD+ (Reducing emissions from deforestation and forest degradation, and foster conservation, sustainable management of forests, and enhancement of forest carbon stocks). The carbon credit which is obtainable through programmes like REDD+ will not only contribute greatly to the sustainable management of the Park but the improvement of the livelihood of the communities around the Park. However, assessing such funds will require monitoring the state and changes of the different carbon pools in the forest, as this is highly essential to carbon trading and marketing (Genene et al., 2013). Presently, information on the stock of the different carbon pools in the Park and monetary value of the carbon stock is lacking. This constitute the major problem this study sought to address.

\section{MATERIALS AND METHOD}

\subsection{Study Area}

The lowland rainforest, Okomu National Park, is located at the heart of Okomu forest reserve in Ovia South-West Local Government, Edo State, Nigeria, with a total size of $202.24 \mathrm{~km}^{2}$ (Nigeria Park Service, 2016). The Park lies 
between longitude $5.187^{\circ} \mathrm{E}$ and $5.431^{\circ} \mathrm{E}$ and latitude $6.278^{\circ} \mathrm{N}$ and $6.435^{\circ} \mathrm{N}$ as shown in Figure 1. The park has four range namely: Igowan range, Arakhuan range, Julius creek range and Babui creek range (Ijeomah et al., 2015).

\subsection{Data Collection}

Nested plot design was adopted for the study and fourteen temporary plot sizes of $50 \mathrm{~m} \mathrm{X} 50 \mathrm{~m}$ were laid within which sub-plots sizes of $20 \mathrm{~m} \mathrm{X} 20 \mathrm{~m}$ and $1 \mathrm{~m} \mathrm{X} 1 \mathrm{~m}$ were marked out, using line transect method. Trees with dbh $\geq 20 \mathrm{~cm}$ were enumerated within the $50 \mathrm{~m} \mathrm{X} 50 \mathrm{~m}$ plots and core samples were collected from those trees using increment borer. Core samples collected were weighed on field and labelled appropriately. In addition, all dead trees/wood encountered were also enumerated within these plots. The dead wood included both standing and lying dead wood. Standing dead trees were classified into three categories based on the presence or absence of leaves, twigs and big branches as recommended by Genene et al. (2013). On the hand, lying dead wood were classified based on their healthiness as either sound, intermediate or rotten using the machete test. Samples obtained from the dead wood were measured using water displacement method and labelled appropriately

Trees with dbh between $10 \mathrm{~cm}$ and $19.9 \mathrm{~cm}$ were enumerated with the $20 \mathrm{~m} \mathrm{X} 20 \mathrm{~m}$ sub-plots while the $1 \mathrm{~m}$ X $1 \mathrm{~m}$ sub-plots were adopted for the collection of litter. The litter was weighed and sub-samples were collected. A total of 531 live trees, 33 standing dead wood and 62 lying dead wood were enumerated within the $50 \mathrm{~m} \mathrm{X} 50$ m plots while 199 live trees were measured within the $20 \mathrm{~m} \mathrm{X} 20 \mathrm{~m}$. All samples collected were later dried in the laboratory and values obtained were used for further analysis.

\subsection{Data Analysis}

Live tree volume, core volume and core density were estimated using Equations 1,2 and 3 respectively.

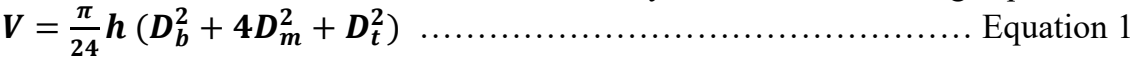

Where $V$ is Volume $\left(\mathrm{m}^{3}\right)$, $h$ is height $(\mathrm{m}), \mathrm{D}_{\mathrm{b}}$ is Diameter at the base $(\mathrm{m}), \mathrm{D}_{\mathrm{m}}$ is Diameter at the middle $(\mathrm{m}), \mathrm{D}_{\mathrm{t}}$ is Diameter at the top (m), and $\pi$ is 3.142 .

$C V=\frac{\pi d^{2}}{4} x L$ Equation 2

Where $\mathrm{d}$ is diameter of the core sample (diameter of the increment borer used) $\mathrm{cm}^{2}$, and $\mathrm{L}$ is mean length of the two core samples that were obtained from each tree $(\mathrm{cm})$.

$\mathrm{WCD}=\mathrm{M} / \mathrm{CV}$ Equation 3

Where WCD is Wood core density $\left(\mathrm{g} / \mathrm{cm}^{3}\right), \quad \mathrm{M}$ is Wood Mass $(\mathrm{g})$ i.e. mean dry weight of the two core samples that were obtained from each tree, and $\mathrm{CV}$ is Core Volume $\left(\mathrm{cm}^{3}\right)$.

Above ground biomass was calculated using Equation 4 while below ground biomass was estimated using simple default value of $25 \%$ (for hardwood species) of the total above ground biomass as recommended by IPCC (2006). The carbon contents of AGB and BGB were estimated by halving their biomass and converting them to tonnes per plot (tons/plot) by dividing it by 1000 .

$B=V \times W C D \times B E F$ Equation 4

Where B is Biomass $(\mathrm{kg}), \mathrm{V}$ is Stem Wood Volume $\left(\mathrm{m}^{3}\right), \mathrm{WCD}$ is Wood Core Density $\left(\mathrm{kg} / \mathrm{m}^{3}\right)$ and BEF is Biomass Expansion Factor (2.292). The mean BEF value of 2.292 was used for this study as prescribed by Nigeria R-PP (2013) for lowland Rainforest National Parks.

Biomass of dead standing tree in categories 1 and 2 were discounted by $3 \%$ to correct for absence of leave. Smalian volume equation given in Equation 5 was used for category 3 of dead standing tree and lying dead wood. The biomass was then estimated using Equation 6.

$V=\pi h \frac{d_{b}^{2}+d_{t}^{2}}{8}$ Equation 5

Where $\mathrm{V}$ is Volume of bole $\left(\mathrm{m}^{3}\right), \mathrm{h}$ is height $(\mathrm{m}), \mathrm{d}_{\mathrm{b}}$ is Diameter at the base $(\mathrm{m})$ and $\mathrm{d}_{\mathrm{t}}$ is Diameter at the top $(\mathrm{m})$ Biomass $(\mathrm{kg})=$ Density $\left(\mathrm{kg} / \mathrm{m}^{3}\right) \times$ Volume $\left(\mathrm{m}^{3}\right)$ Equation 6

The dry mass of the litter sample was estimated from the dry to wet ratio of the sub-sample using Equation 7. Dry Mass of sample $(\mathrm{kg})=\frac{\text { sub-sample dry mass }(\mathrm{kg})}{\text { sub-sample wet mass }(\mathrm{kg})} \times$ Fresh Mass of sample $(\mathrm{kg}) \quad$........ Equation 7

The result obtained was divided by 2 to obtain the amount of carbon in the litter, this was then expressed in tonnes per plot by dividing it by 1000 . The resulting value was multiplied by 10,000 (the number of $1 \mathrm{~m} \mathrm{X} 1 \mathrm{~m}$ in a hectare) to obtain the amount in tonnes per hectare.

The total carbon stock in tonnes per hectare for the study area was estimated by summing up the carbon in tonnes per hectare of all the pools estimated, the formula is given in Equation 8.

$C t_{\frac{\text { tons }}{h a}}=C a b_{\frac{\text { tons }}{h a}}+C b g_{\frac{\text { tons }}{h a}}+C s d w_{\frac{\text { tons }}{h a}}+C l d w_{\frac{\text { tons }}{h a}}+$

Cltons

Where $\mathrm{Ct}$ is Total carbon (tons/ha), Cab is Estimated Carbon in Above-ground biomass (tons/ha), Cbg is Estimated 
Carbon in below-ground biomass (tons/ha), Csdw is Estimated Carbon in standing dead wood (tons/ha), Cldw is Estimated Carbon in Lying dead wood (tons/ha), and $\mathrm{Cl}$ is Estimated Carbon in litter (tons/ha).

The estimated total carbon in tons/ha obtained was used to estimate the Carbondioxide equivalent in tons/ha using Equation 9 as stipulated by IPCC (2006).

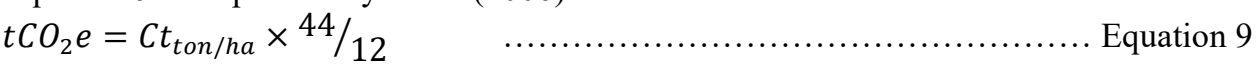

Where $\mathrm{tCO}_{2} \mathrm{e}$ is Total Carbondioxide equivalent in tons/ha, and $\mathrm{Ct}_{\text {tons/ha }}$ is Total carbon (tons/ha).

The total carbon and Carbondioxide equivalent for the entire stand were then estimated using Equations 10 and 11 respectively.

$C t_{\text {stand }}=C t_{\text {tons } / \text { ha }} \times 20224 h a$ Equation 10

Where $C t_{\text {stand }}$ is Total Carbon for the stand (tons), and $\mathrm{Ct}_{\text {tons/ha }}$ is Total carbon (tons $/ \mathrm{ha}$ ).

$\mathrm{CO}_{2} e_{\text {stand }}=t \mathrm{CO}_{2} e \times 20224 \mathrm{ha} \quad \ldots \ldots \ldots \ldots \ldots \ldots \ldots \ldots \ldots \ldots \ldots \ldots \ldots \ldots \ldots \ldots$ Equation 11

Where $\mathrm{CO}_{2} e_{\text {stand }}$ is Total Carbondioxide equivalent for the stand (tons) and $\mathrm{tCO}_{2} \mathrm{e}$ is Total Carbondioxide equivalent in tons/ha

The price for the carbon stock was estimated by multiplying the total Carbondioxide for the whole stand by $\$ 4$ as done by Assaye (2014). This is given in Equation 12.

Carbon Price $=\mathrm{CO}_{2} e_{\text {stand }} \times \$ 4$ Equation 12

\section{RESULTS AND DISCUSSION}

The total carbon stock estimated for the various pools was $177.58 \pm 8.91$ tons/ha. The values estimated for AGB, BGB, SDW, LDW and litter were 2,710,256.24 tons, 677,564.06 tons, 59,047.37 tons, 63,367.54 tons and $81,220.19$ tons respectively, giving a total of 3,591,455.39 tons for the entire stand, details are presented in Table 1. The results, as illustrated in Figure 2, shows that AGB had the highest carbon stock constituting about $75 \%$ of the total carbon stock, this was followed by BGB constituting about $19 \%$ of the total estimated carbon stock. Dead wood (comprising of LDW and SDW) and litter had the least values.

Total carbon stock (177.58 tons/ha ) obtained was higher than 127.3 tons/ha predicted for lowland National Parks by Nigeria R-PP (2013) and the estimated 115 tons/ha reported by Pandey (2012) for World Heritage Sites in Tropical Forests. It was also higher than 77.64 tons/ha estimated by Pragasan (2015) for a forest in India, 120 tons/ha reported by Lai (2005) for a tropical ecosystem, 123.58 tons/ha reported by Jibrin et al. (2014) for a riparian forest in Nigeria. The value obtained was also higher than 123.05 tons $/ \mathrm{ha}(\mathrm{dbh} \geq 10 \mathrm{~cm})$ reported by Zaragoza et al. (2016) for a secondary tropical forest and the 138 tons/ha recorded by Pandey (2012) for a rainforest in Madagascar. It was closely comparable to 160 tons/ha and 186.43 tons/ha reported by GRCL (2015) and Karki et al. (2016) for some tropical forests and 198.4 tons/ha $(\mathrm{dbh}>10 \mathrm{~cm})$ estimated by Alves et al. (2010) in a lowland forest in Brazil. Kupsch et al. (2014), Hunter et al. (2013), Berta et al. (2015), Glenday (2006) and Alder and Van Kuijk (2009) however reported higher values of 271.3 tons/ha, 288 tons/ha, 324.89 tons/ha, 360 tons/ha, 372 tons/ha, for similar forests in Cameroon, Brazil, Ethopia, Kenya and Guyana respectively.

When compared with values for other National Parks and World Heritage sites as estimated by Pandey (2012), total carbon stock of the study area was higher than that obtained for Sundarbans National Park (56.3 tons/ha) in India and Sangay National Park (67.5 tons/ha) in Ecuador. It was also higher than those estimated for Tikal National Park ( 85 tons/ha) in Guatemala, Canaima National Park (92 tons/ha) in Venezuela, and Lorentz National Park (100 tons/ha) in Indonesia. It was higher than the estimated values for Manu National Park (134.4 tons/ha), Peru, Chitwan National Park (140.7 tons/ha), Nepal and Gunung Mulu National Park (167 tons/ha), Malaysia. It was however in the range reported for Sangha Trinational (163 tons/ha), (bordering Cameroon, Central African Republic and Republic of Congo) and Taï National Park (188 tons/ha), Cote d'Ivoire. The Carbondioxide equivalent of carbon estimated followed the same trend since it was a derivate of estimated carbon. The carbon stock of the Park also falls within the high carbon density area (158-408 tons/ha) as classified by Ravilious et al. (2010). Given that the forest is a regenerating forest, it has a high capacity to sequester even more carbon with improved management.

The result obtained for the financial estimate is presented in Table 2, the total monetary value for the carbon stock estimated at $\$ 4 / \mathrm{tCO} 2$ was $\$ 52,674,679$. The estimated monetary value of carbon stock obtained for the Park was greater than US\$ 40,709,088 estimated by Assaye (2014) for Awash National Park but lesser than US\$ 62,184,364 reported for Simien Mountains National Park by Assaye (2015). These values are subjective depending on estimated carbon stock per hectare, size of area being assessed and the price per tonne adopted. However, the value obtained for the Park has the potential of providing adequate funds through programmes such as REDD+ if carbon stock is incorporated as a management objective. This will help in providing additional funds for the management of the Park and also make available financial incentives for forest dependent communities, thereby reducing the pressure on the forest. 


\section{CONCLUSION}

For the carbon stock estimations of Okomu National Park, above ground biomass accounted for the largest proportion of carbon within the Park, followed by below ground biomass, and then Dead wood (Both standing and lying dead wood). Litter accounted for the least carbon stock within the Park. The carbon stock estimated for the National Park is highly significant and falls within the high Carbon density area. More so, since the forest is a regenerating forest, higher values can be attained with good conservation efforts. The monetary value of carbon stock obtained for the Park was very high and if accessed could be useful in funding management cost as well as providing incentives for forest dependent communities around the Park.

\section{REFERENCES}

Ajayi, S. (2011). Multipurpose Forest Management for Bush Meat Production: A Success story from West Africa. Retrieved August 8, 2016, from FAO: http://www.fao.org/forestry/102580c60dbb6d55b4eb656bacabf3808aa4a3.pdf

Akinsorotan, O., Ogunjemite, B., \& Afolayan, T. (2011). Assessment of the Large Mammals of Arakhuan Range, Okomu National Park. Ethiopian Journal of Environmental Studies and Management, 4(3), 25-37.

Alder, D., \& van Kuijk, M. (2009). A baseline assessment of forest carbon in Guyana. Guyana Forestry Commission.

Alves, L., Vieira, S., Scaranello, M., Camargo, P., Santos, F., Joly, C., \& Martinelli, L. (2010). Forest structure and live aboveground biomass variation along an elevational gradient of tropical Atlantic moist forest (Brazil). Forest Ecology and Management, 1-13. doi:10.1016/j.foreco.2010.05.023

Amusa, T. (2016). Spatial distribution and conservation of forest elephants (Loxodonta africana cyclotis) in Southwestern Nigeria. 6th Floor, 248 Tottenham Court Road London W1T 7QZ: Rufford small grants foundation (for nature conservation).

Aremu, O., Emelue, G., Osayimwen, F., \& Obasogie, F. (2012). Estimate of Habitat Quality of White Throated Monkey (Ceropithecus erythrogaster) in Okomu National Park, Nigeria. Nigerian Journal of Agriculture, Food and Environment, 8(1), 47-51.

Assaye, H. (2014). Determination of Conservation Benefits and Carbon Sequestration Capacity of the Awash National Park of Ethiopia. Addis Ababa, Ethiopia: Population, Health and Environment Ethiopia Consortium (PHEEC).

Assaye, H. (2015). Determination of Conservation Benefits and Carbon Sequestration Potential of the Simien Mountains National Park, Ethiopia. Population, Health and Environment Ethiopia Consortium (PHEEC).

Berta, A., Soromessa, T., \& Belliethathan, S. (2015). Carbon Stock of Gambella National Park: Implication for Climate Change Mitigation. Advances in Life Science and Technology, 41-55.

Ejidike, B., \& Okosodo, F. (2007). Food and Feeding Habit of Thick-Tailed Galago (Otelemur crassicaudatos in Okomu National Park. Journal of Fisheries International, 2(3), 231-233.

Genene, A., Tefera, M., Zerihun, G., \& Solomon, Z. (2013). Training Manual on Forest Carbon Pools and Carbon Stock Assessment in the Context of SFM and REDD+. Wondo Genet, Ethopia: Hawassa University Wondo Genet College of Forestry and Natural Resources.

Glenday, J. (2006). Carbon storage and emissions offset potential in an East African tropical rainforest. Forest Ecology and Management, 235, 72-83.

Gola Rainforest Conservation LG (GRCL). (2015). The Gola REDD Project. UK: Tropical Forest Unit, RSPB.

Hunter, M., Keller, M., Victoria, D., \& Morton, D. (2013). Tree height and tropical forest biomass estimation. Biogeosciences, 10, 8385-8399.

Ijeomah, H., Nwanegbo, O., \& Umokoro, O. (2015). Assessment of Tourist Attractions in Okomu National Park and Oguta Lake Eco-destinations of Nigeria. Production Agriculture and Technology, 11(2), 219-239.

IPCC. (2006). Chapter 4: Forest Land. In Inventories, 2006 IPCC Guidelines for National Greenhouse Gas, Volume 4: Agriculture, Forestry and Other Land Use (pp. 4.81-4.83).

Jibrin, A., Zubairu, S., \& Kaura, S. (2014). Carbon Sequestration Potential of Kpashimi Forest Reserve, Niger State, Nigeria. Journal of Geography and Earth Sciences, 2(1), 149-163.

Karki, S., Joshi, N., Udas, E., Adhikari, M., Sherpa, S., Kotru, R., . . . Ning, W. (2016). Assessment of Forest Carbon Stock and Carbon Sequestration Rates at the ICIMOD Knowledge Park in Godavari. ICIMOD Working Paper 2016/6.

Kupsch, D., Serge, B., \& Waltert, M. (2014). Biodiversity, carbon stock and market value assessment for the SGSOC project area, Southwest region, Cameroon. World Wide Fund for Nature, Germany, and Greenpeace International.

Lal, R. (2005). Soil Carbon Sequestration in Natural and Managed Tropical Forest Ecosystems. (F. Montagnini, Ed.) Journal of Sustainable Forestry, 1-30.

Morgan, B., \& etal. (2011). Regional Action Plan for the Conservation of the Nigeria-Cameroon Chimpanzee (Pan troglodytes ellioti). CA, USA: IUCN/SSC Primate Specialist Group and Zoological Society of San Diego. 
Nigeria Park Service. (2016). National Parks Overview. Retrieved December 4, 2016, from Nigeria National Park: http://nigeriaparkservice.org/?page_id=53

Nigeria R-PP. (2013). REDD+Readiness Preparation Proposal (R-PP). Federal Republic of Nigeria.

Oates, J. (1995). 'The dangers of conservation by rural development-a case-study from the forests of Nigeria. Oryx, 29, 115-122.

Obasogie, F., \& Ogunjemite, B. (2014). Population Status of White Throated Monkey (Cercopithecus erythrogaster pococki) in Okomu National Park of Nigeria. Global Journal of Bio-science and Biotechnology, 3(1), 63-69.

Ogunjemite, B., Ajayi, B., \& Agbelusi, E. (2007). Habitat structure of chimpanzee communities in Nigeria: a comparison of sites. Acta Zoological Sinica, 53(4), 579-588.

Ogunjinmi, A., Onadeko, S., \& Adewunmi, A. (2012). An Emperical study of the effects of personal factors on Environmental Attitud of local Communities around Nigeria's Protected areas. The Journal of Transdisciplinary Environmental Studies, 11(1), 40-53.

Ojianwuna, C. (2015). Climatic Variables as Factors Affecting Diversity and Abundance of Butterflies in Okomu National Park, Edo State, Nigeria. Journal of Natural Sciences Research, 5(2), 70-76.

Pandey, D. (2012). Carbon stock of World Heritage Forest Sites. UNESCO World Heritage Site.

Pragasan, L. (2015). Total Carbon Stock of Tree Vegetation and its Relationship with Altitudinal Gradient from the Shervarayan Hills Located in India. Earth Science and Climatic Change, 6(4), 1-5.

Ravilious, C., Kapos, V., Osti, M., Bertzky, M., Bayliss, J., Dahiru, S., \& Dickson, B. (2010). Carbon, biodiversity and ecosystem services: Exploring co-benefits. Nigeria: Preliminary Results. Cambridge, UK: UNEPWCMC.

Tessema, M., Lilieholm, R., \& Leader-Williams, N. (2007). Community attitudes towards wildlife conservation in Ethiopia. Protected Area in a Changing World (pp. 287-292). Proceedings of the 2007 George Wright Society Conference.

Zaragoza, M., Aranico, E., Tampus, A., \& Amparado Jr., R. (2016). Carbon stock assessment of three different vegetative covers in Kapatagan, Lanao del Norte, Philippines. Advances in Environmental Sciences International Journal of the Bioflux Society, 8(2), 205-220.

\section{FIGURES}

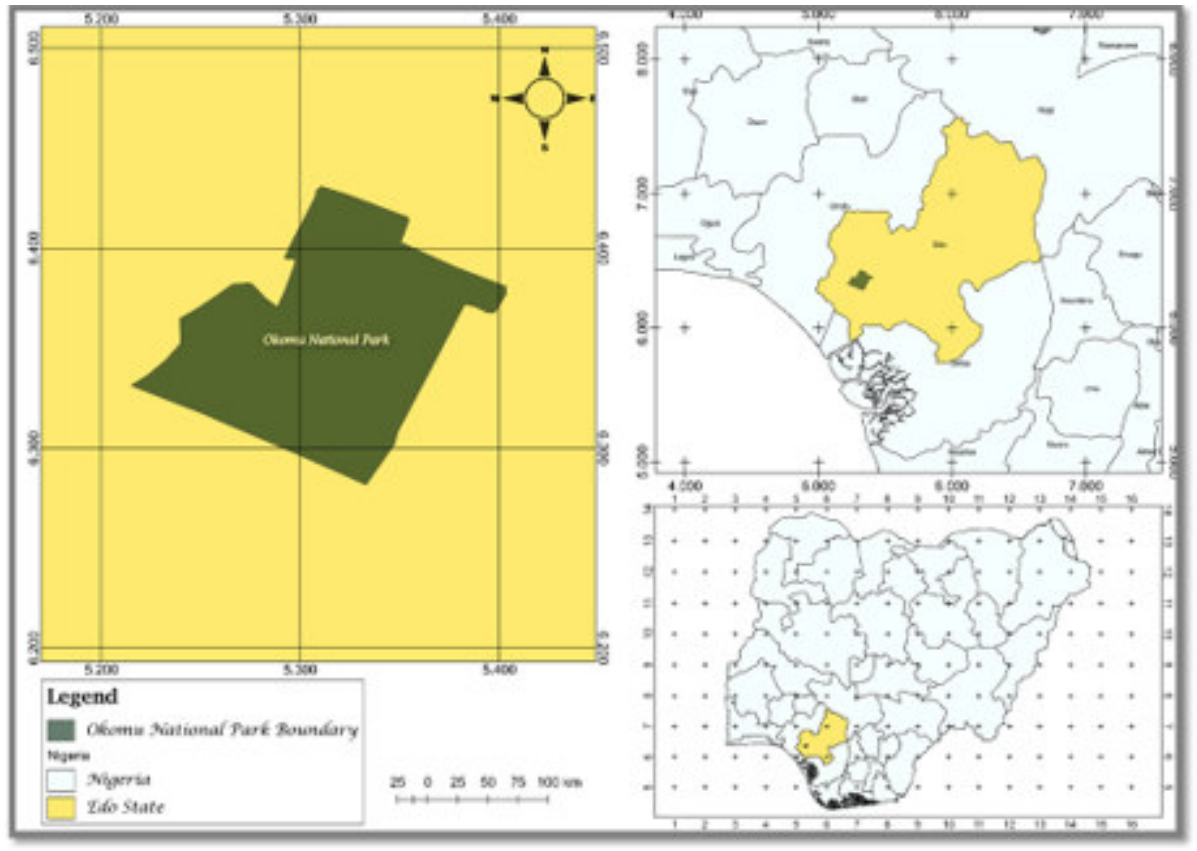

Figure 1: Boundary Map of Okomu National Park 


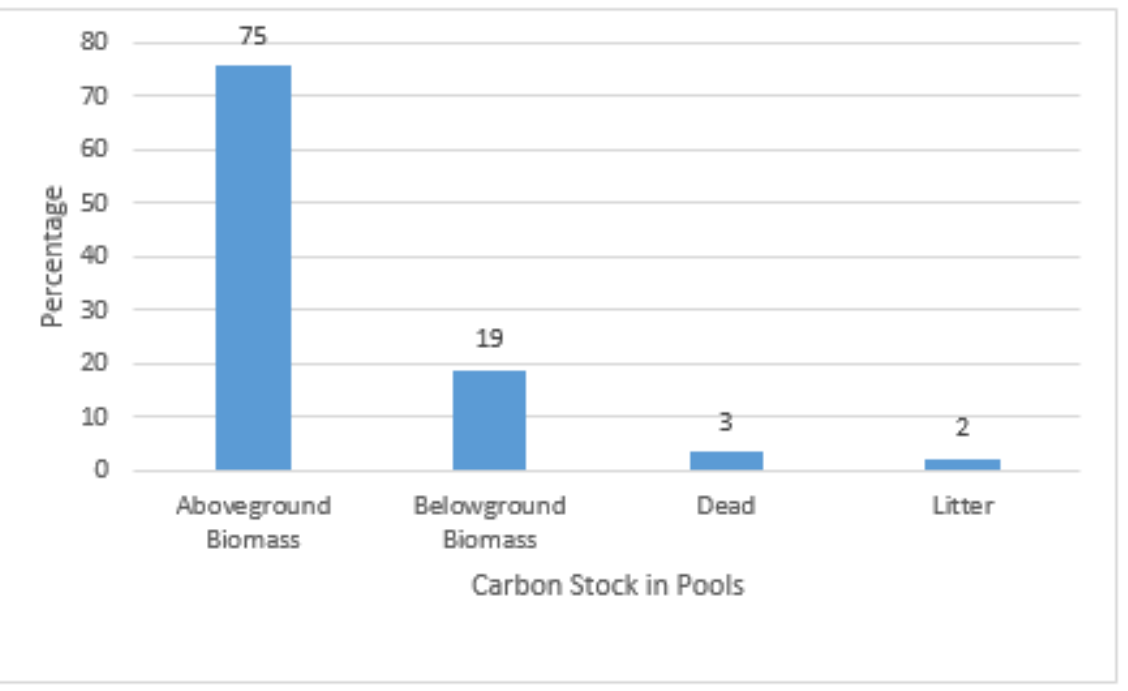

Figure 2: Comparison of Carbon Stock in different Carbon Pools

\section{TABLES}

Table 1: Carbon Stock and Carbondioxide Equivalent of the Carbon Pools

\begin{tabular}{llllllll}
\hline $\begin{array}{l}\text { Total } \\
\text { Number } \\
\text { of Plots }\end{array}$ & $\begin{array}{l}\text { Cab } \\
\text { tons/ha }\end{array}$ & $\begin{array}{l}\text { Cbg } \\
\text { tons/ha }\end{array}$ & $\begin{array}{l}\text { Csdw } \\
\text { tons/ha }\end{array}$ & $\begin{array}{l}\text { Cldw } \\
\text { tons/ha } / \mathbf{h a}\end{array}$ & $\begin{array}{l}\text { Cl } \\
\text { tons/ha }\end{array}$ & Ct Tons/ha & tCO2e \\
\hline $\mathbf{1 4}$ & 1876.17 & 469.04 & 40.88 & 43.87 & 56.22 & 2486.17 & 9115.97 \\
Avg & 134.01 & 33.50 & 3.41 & 3.13 & 4.02 & 177.58 & 651.14 \\
Per ha & 134.01 & 33.50 & 2.92 & 3.13 & 4.02 & 177.58 & 651.14 \\
Per Stand & 2710256.24 & 677564.06 & 59047.37 & 63367.54 & 81220.19 & 3591455.39 & 13168669.78 \\
Mean & 134.01 & 33.50 & 3.41 & 3.13 & 4.02 & 177.58 & 651.14 \\
Std Dev & 56.36 & 14.09 & 4.57 & 8.54 & 1.71 & 68.21 & \\
C1(95\%) & 29.52 & 7.38 & 2.39 & 4.47 & 0.90 & 35.73 & \\
\hline
\end{tabular}

Table 2: Monetary value of Carbon Stock

\begin{tabular}{ccc}
\hline Plot No & tCO$_{\mathbf{2}} \mathbf{e}$ & Price Equivalent $\mathbf{( \$ )}$ \\
\hline 1 & $1,174.40$ & $4,697.59$ \\
2 & 679.32 & $2,717.27$ \\
3 & 629.02 & $2,516.08$ \\
4 & 593.69 & $2,374.76$ \\
5 & 762.35 & $3,049.42$ \\
6 & 846.84 & $3,387.34$ \\
7 & 681.37 & $2,725.48$ \\
8 & 239.73 & 958.91 \\
9 & 568.81 & $2,275.26$ \\
10 & 440.15 & $1,760.61$ \\
11 & 907.09 & $3,628.36$ \\
12 & 813.31 & $3,253.23$ \\
13 & 520.93 & $2,083.72$ \\
14 & 258.96 & $1,035.84$ \\
Total & $9,115.97$ & 36463.88 \\
Per ha & 651.14 & 2604.56 \\
Per Stand & $13,168,669.78$ & $52,674,679.12$ \\
\hline
\end{tabular}

$* \mathrm{tCO}_{2} \mathrm{e}=$ Total Carbondioxide equivalent of Carbon 